\title{
Canadian Anaesthetists' Society 53rd Annual Meeting
}

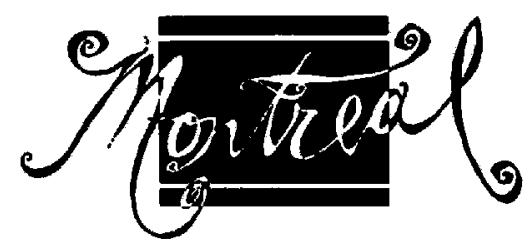

Queen Elizabeth Hotel, Montreal, Quebec

June 14-18, 1996

\section{CALL FOR ABSTRACTS}

\section{POSTER-DISCUSSION SESSIONS}

Abstracts are invited for both poster discussion and poster display sessions. Abstracts must give a clear description of the project, with results, and must conform to a set length and format. Those accepted for presentation will be published in the Annual Meeting Supplement of the Canadian Journal of Anaesthesia.

\section{RESIDENTS' COMPETITION}

Abstracts are also invited for inclusion in the Residents' Competition. Candidates must be members of the Canadian Anaesthetists' Society at the time of the competition, and occupy the position of Resident, Fellow or Research Fellow in a Canadian Department of Anaesthesia.

The work must have been carried out in Canada and completed in the preceding 18 months.

The Chairs of Canadian University Departments of Anaesthesia (or their deputies) will act as judges. Three special plaques will be awarded to the best of the papers presented at the meeting. The papers to be presented will be selected by the Scientific Programme Committee from abstracts received by December 8,1995 . The quality of the abstract will be included in the final score at the competition. Abstracts of papers to be presented will be published in the Annual Meeting Supplement of the Canadian Journal of Anaesthesia.

\section{N.B. THE CANADIAN ANAESTHETISTS' SOCIETY WILL NOT CONSIDER A SUBMITTED} ABSTRACT AS AN ENTRY FOR THE RESIDENTS' COMPETITION UNLESS

a) the "Residents' Competition" box on the Abstract Covering Form has been ticked, and

b) the Department Head has confirmed the resident status of the author by signing the form.

Those entries not selected for inclusion in oral competitions may be selected for presentation in other poster sessions.

(A complete set of rules for the competition is available on request.)

Abstracts must be submitted on forms which are available from and should be returned to:

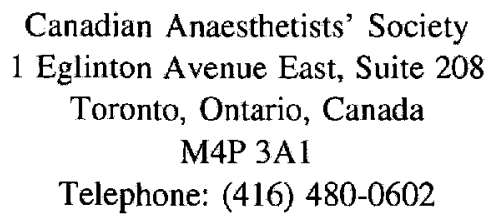

Absolute Deadline for receipt of abstracts is December 8, 1995. Send abstracts to the Society office at the above address. 


\title{
$53^{\mathrm{e}}$ Congrès annuel de la Société canadienne des anesthésistes
}

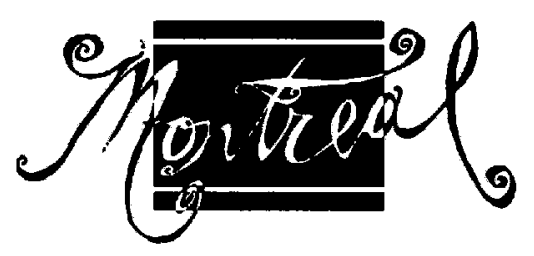

\author{
L'Hôtel La Reine Elizabeth, Montréal (Québec) \\ du 14 au 18 juin 1996
}

\section{INVITATION À PRÉSENTER DES RÉSUMÉS}

\section{Exposés sur affiche}

Nous sollicitons des résumés pour les exposés sur affiche et les discussions illustrées. Les résumés doivent décrire clairement le projet et le résultat obtenu; ils doivent suivre le format de présentation et respecter la longueur imposée. Les résumés qui seront retenus pour présentation seront publiés dans le supplément du congrès annuel du Journal canadien d'anesthésie.

\section{Concours des résidents}

Nous sollicitons aussi des réșumés pour le Concours des résidents. Les candidats doivent faire partie de la Société canadienne des anesthésistes au moment du concours et occuper un poste de résident, de chercheur ou de stagiaire en recherche dans un département d'anesthésie au Canada.

Le travail doit avoir été effectué au pays et avoir été terminé dans les dix-huit mois précédant le concours.

Les présidents des départem̄ents d'anesthésie des universités canadiennes, ou leurs représentants, forment le jury. Trois plaques spéciales seront décernées aux meilleurs exposés. Le Comité des activités scientifiques choisira les exposés à présenter parmi ceux qui auront été reçus au 8 décembre 1995. On tiendra compte de la qualité du résumé dans la note finale. Les résumés retenus seront publiés dans le supplément du congrès annuel du Journal canadien d'anesthésie.

\section{À NOTER : LA SOCIÉTÉ CANADIENNE DES ANESTHÉSISTES N'ACCEPTERA D'INSCRIRE UN RÉSUMÉ AU CONCOURS DES RÉSIDENTS QUE SI}

A) la case « Concours des résidents » est cochée sur le formulaire prescrit devant accompagner le résumé;

B) le chef de département a confirmé le statut de résident du l'auteur en signant le formulaire en question.

Les candidatures qui n'auront pas été retenues pour les concours oraux pourront quand même être choisies pour présentation comme exposés sur affiche.

(On peut obtenir sur demande les règles du concours.)

Les résumés doivent ètre présentés sur des formulaires qu'on peut se procurer ả l'adresse suivante, oủ il faudra également les renvoyer :

Société candienne des anesthésistes

1, avenue Eglinton Est, Bureau 208

Toronto (Ontario) Canada

M4P $3 \mathrm{Al}$

Téléphone : (416) 480-0602

Les candidatures devront être reçues au bureau de la Société au plus tard le 8 décembre 1995. 